Filol. Linguíst. Port., São Paulo, v. 16, n. spe, p. 163-197, dez. 2014 http://dx.doi.org/10.11606/issn.2176-9419.v16ispep163-197

\title{
O Efeito V2 na história do espanhol e português europeus
}

\section{The V2 order in the history of European Spanish and Portuguese}

\author{
Carlos Felipe Pinto * \\ Universidade Federal da Bahia, Salvador, Bahia, Brasil \\ André Luis Antonelli ** \\ Universidade Federal de Pelotas, Pelotas, Rio Grande do Sul, Brasil
}

\begin{abstract}
Resumo: Abordamos a perda do efeito V2 na história do espanhol e do português europeus. Para isso, discutimos o que entendemos como língua V2, assumindo que efeito V2 implica em movimento do verbo para CP; apresentamos os argumentos que nos levam a analisar o espanhol antigo e o português antigo e clássico como línguas V2 e as possíveis causas das mudanças linguísticas; por fim, fazemos algumas consideraçôes sobre como o contato de línguas na Península Ibérica pode ter influenciado na mudança linguística nas duas línguas.
\end{abstract}

Palavras-chave: Ordem de constituintes. Efeito V2. Mudança linguística.

Abstract: We approach the loss of the V2 effect in the history of Spanish and European Portuguese. In this context, we discuss what we understand as Verb Second, assuming that the V2 order involves verb movement to CP. We then argue why we analyze Old Spanish as well as Old and Classical Portuguese as V2 languages and present possible causes of such language change. Finally, we comment on how language contact in Iberia may have influenced language change in both languages.

* Professor do Departamento de Letras Românicas da Universidade Federal da Bahia - UFBA, Salvador, Bahia, Brasil; cfpinto@ufba.br.

* Professor do Centro de Letras e Comunicação da Universidade Federal de Pelotas - UFPel, Pelotas, Rio Grande do Sul, Brasil; andre.antonelli@ufpel.edu.br. 
Keywords: Word order. Verb second; Language change.

\section{INTRODUÇÃO'}

A partir dos anos 80 com o desenvolvimento da Teoria de Princípios e Parâmetros por Chomsky $(1981,1986)$ e os trabalhos pioneiros de Lightfoot $(1979,1991)$ procurando explicar a mudança linguística dentro do quadro mentalista da gramática gerativa, vários estudos foram desenvolvidos para descrever e explicar a mudança linguística (em especial a mudança sintática) em diferentes línguas. No âmbito dos estudos sobre as línguas românicas, um enfoque especial tem sido dado às diferenças entre as fases antigas e as fases modernas no que diz respeito à sintaxe da ordem de palavras e à posição do verbo finito na sentença. Uma hipótese amplamente defendida é a de que as línguas românicas antigas, em contraposição às variedades modernas, se comportavam como línguas V2, à semelhança das línguas germânicas atuais (Adams, 1987 para o francês; Fontana, 1993 para o espanhol; Ribeiro, 1995 para o português $)^{2}$.

O objetivo do nosso trabalho é fazer uma síntese da perda do efeito V2 na história do espanhol e do português e levantar uma questão que deverá ser desenvolvida com bastante cautela em trabalhos futuros. Neste sentido, procuramos levantar o problema de como a diacronia do espanhol e do português se inter-relacionam no que diz respeito ao efeito V2. Nossa hipótese inicial é que, considerando os intensos contatos que a sociedade espanhola e a sociedade portuguesa mantiveram na idade média, a mudança gramatical do espanhol, que aconteceu por razóes independentes de questôes sócio-históricas, é a causa, ou pelo menos o acelerador, da mudança gramatical no português.

1 Este trabalho é resultado das discussões levantadas independentemente nas nossas teses de doutorado: Pinto (2011) e Antonelli (2011), ambas orientadas pela Profa. Dra ${ }^{\mathrm{a}}$. Charlotte Galves e financiadas pela Fundação de Amparo à Pesquisa do Estado de São Paulo (FAPESP), trabalhos aos quais o leitor deve se remeter para o detalhamento, suporte e evidências mais robustas para os dados e análises apresentados neste breve artigo. Nosso trabalho se detém na história do português e do espanhol europeus. Doravante, só utilizaremos a especificação "europeu" quando houver a necessidade de contraposição com outras variedades da língua.

2 Esta análise não é isenta de críticas: Kayser (1999, 2006) e Rinke (2009), entre outros, se posicionam contra a análise do português antigo como língua V2; Cruschina e Sitaridou (2009) se posicionam contra a análise de que as línguas românicas como um todo eram línguas V2; Rivero (1992) não discute a questão, mas assume que o verbo está em IP no espanhol antigo. Em Pinto (2011) se faz um debate sobre esta questão advogando que as línguas românicas antigas eram línguas V2.

Pinto CF, Antonelli AL. O Efeito V2 na história do espanhol e português europeus 
O trabalho está dividido da seguinte maneira: na seção 2, discutimos algumas questôes referentes ao efeito V2 nas línguas germânicas, apresentando as análises tradicionais para o efeito V2 simétrico e assimétrico e, em seguida, uma proposta alternativa para explicar a variação do efeito V2, uma vez que é a partir desse referencial que se analisam as línguas românicas antigas. Na seção 3, discutimos a perda do efeito V2 na história do espanhol. Na seção 4, discutimos a perda do efeito V2 na história do português. Na seção 5, procuramos relacionar a perda do efeito V2 aos aspectos sócio-históricos das duas línguas. Na seção 6, tecemos nossas consideraçôes finais.

\section{CONSIDERAÇÓES SOBRE O EFEITO V2 NAS LÍNGUAS HUMANAS}

$\mathrm{O}$ efeito V2, tal como atestado especialmente nas línguas germânicas atuais (à exceção do inglês), caracteriza-se como uma exigência na ordem de palavras determinando que o verbo finito apareça na segunda posiçáo da sentença precedido exclusivamente por um constituinte qualquer, independentemente de sua função sintática ${ }^{3}$. Quando o sujeito não é o constituinte em primeira posição, este segue imediatamente o verbo. Vejam-se os exemplos em (1) do africâner, uma típica língua $\mathrm{V} 2^{4}$.

(1) a. André het gister die storie geskryf André tem ontem a história escrito

b. Gister het André die storie geskryf

Ontem tem André a história escrito

c. Die storie het André gister geskyrf

A história tem André ontem escrito

d. Nêrens praat mense meer Latyn nie Em nenhum lugar falam as pessoas mais latim

3 Com relação ao estatuto informativo desse constituinte em primeira posição, parece que há algum tipo de variação paramétrica. Por exemplo, Hinterhölzl e Petrova (2010) comentam que, no alemão moderno, o XP em primeira posição deve possuir um traço [+tópico]. Em casos em que não há um elemento [+tópico] na sentença, o sujeito é o constituinte que se move obrigatoriamente para a primeira posição para satisfação do efeito V2 devido à restrição Minimal Link Condition proposta por Chomsky (1995). Cruschina e Sitaridou (2009) propóem que, nas românicas antigas, o efeito V2 também desempenhava um papel discursivo de focalização ou topicalização. Contudo, como foi mostrado em Pinto (2011) para o caso do espanhol antigo, o fronteamento de um XP para a primeira posição não tem relação nenhuma com fatores discursivos.

4 Destacamos em negrito nos exemplos, em todo o texto, o verbo ao qual nos referimos.

Pinto CF, Antonelli AL. O Efeito V2 na história do espanhol e português europeus 
e. Wat lees jy vandag?

O que lê você hoje (Biberauer, 2002, p. 19)

Outra questão empírica interessante com relação às línguas V2 é o fato de que há línguas que somente exibem o efeito V2 em oraçóes matrizes, como o alemão, o holandês e o norueguês (as línguas assimétricas), e há línguas que exibem o efeito V2 tanto em orações matrizes como em oraçóes subordinadas, como o islandês e o iídiche (as línguas simétricas). Vejam-se os exemplos em (2) e (3) do alemão e do iídiche respectivamente:

(2) a. Das Buch kauft Hans gestern.

O livro comprou Hans ontem

b. ... dass Hans das Buch gestern kauft 5 .

que Hans o livro ontem comprou (Torres Morais, 1995, p. 64)

(3) a. Oyfn veg vet dos yingl zen a kats.

$\mathrm{Na}$ avenida vai o menino ver um gato

b. Oyb oyfn veg vet dos yingl zen a kats.

Se na avenida vai o menino ver um gato (Santorini, 1995, p. 54)

Em termos teóricos, Haider e Prinzhorn (1986: 3) pontuam que a investigação sobre as línguas V2 tem encontrado os seguintes problemas principais: a) qual é o gatilho para o efeito V2?; b) o efeito V2 é uma propriedade paramétrica?; c) qual é o lugar de pouso do verbo?; d) qual é a natureza da assimetria (entre oraçôes principais e subordinadas)?; e) como o efeito V2 pode surgir ou desaparecer em termos diacrônicos?

5 No caso das línguas assimétricas, a posição do verbo é variável: pode ser final, como ilustrado em (2b) com o dado do alemáo, ou pode ser medial, como ilustrado abaixo em (i) com dado do norueguês.

(i) ....at Jens ikke skjØnte dette apØrmálet.

que Jean não entendeu esta questão (Taraldsen, 1986, p. 8)

No modelo de Regência e Ligação, a variação entre V-final e V-medial era explicada pelo diferente posicionamento dos núcleos: línguas com verbo final seriam línguas com núcleo final e línguas com verbo medial seriam línguas com núcleo inicial. Seguindo a proposta de Kayne (1994), acreditamos que a explicação da diferença dos dois posicionamentos lineares do verbo se deve a outros fatores, como movimento de constituintes, e não ao diferente posicionamento dos núcleos. Essa discussão, contudo, não está no escopo da nossa proposta. 
Nesta seção, nos deteremos principalmente na questão (d), ou seja, na questão da simetria/assimetria do efeito V2 e, consequentemente, discutiremos qual é o lugar de pouso para o movimento do verbo em cada caso, que é a questão (c). As perguntas (a) e (b) estão relacionadas na discussão sobre os pontos (c) e (d). Nas seçôes 3 e 4, discutiremos a questâo (e) a partir dos dados diacrônicos do espanhol e do português.

\subsection{O lugar de pouso do verbo nas línguas V2}

\subsubsection{As línguas assimétricas}

Com base em dados de línguas como o alemão e o holandês, den Besten (1989) ${ }^{6}$ propóe que o verbo finito se move para COMP (equivalente a $\mathrm{C}$ no modelo atual) nas línguas V2 assimétricas. Um dos argumentos para essa proposta vem do fato de que o holandês tem dois tipos de sujeitos pronominais: pronomes fortes, como jij (você), hij (ele), zij (ela) e wij (nós); e pronomes fracos, como je (você), hij/ie (ele), ze (ela) e we (nós). Os pronomes fracos devem estar adjacentes ao complementizador nas oraçóes subordinadas, como ilustra o contraste de gramaticalidade em (4):

(4) a. --, dat je/ze gisteren ziek was

que você/ela ontem doente estava

b. ${ }^{*-}$, dat gisteren je/ze ziek was

que ontem você/ela doente estava (Den Besten, 1989, p. 25)

Considerando que a posição canônica do complementizador é COMP, a previsão que os exemplos em (4) fazem é que, se a análise do movimento do verbo para COMP em oraçóes V2 estiver correta, tais sentenças V2 também devem apresentar o verbo finito adjacente a pronomes fracos. Tal previsão é comprovada em (5) a seguir:

(5) a. Toch was ze gisteren ziek.

Ainda ela estava ontem doente

b. *Toch was gisteren ze ziek.

Ainda estava ontem *ela doente (Den Besten, 1989, p. 26)

6 Den Besten (1989) é uma republicação. Taraldsen (1986) também propõe que o verbo se move para COMP. 
A proposta de Den Besten (1989) para as línguas V2 como alemão, holandês e sueco pode ser adaptada na estrutura em (6) a seguir:

(6) a. Oraçóes matrizes

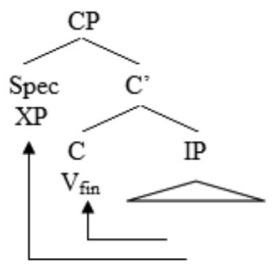

b. Oraçóes subordinadas

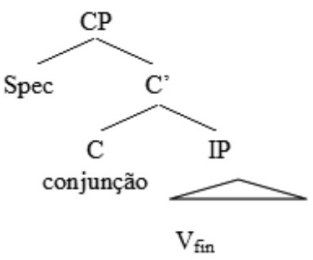

Nas oraçóes matrizes, o verbo se move para C e um XP qualquer se move para a posição de SpecCP. Nas oraçóes subordinadas os dois movimentos são bloqueados devido à presença do complementizador.

\subsubsection{As línguas simétricas}

Como comentamos acima, há outro grupo de línguas V2 que não exibe a assimetria entre oraçóes principais e subordinadas. O efeito V2, nessas línguas, é generalizado. Os dados do iídiche em (7) e do islandês em (8) ilustram esse fato:

(7) a. Oyfn veg vet dos yingl zen a kats.

$\mathrm{Na}$ avenida vai o menino ver um gato

b. Oyb oyfn veg vet dos yingl zen a kats.

Se na avenida vai o menino ver um gato (Santorini, 1995, p. 54)

(8) a. Helgi hefur trúlega keypt bókina.

Helgi tem provavelmente comprado o livro

b. Jón segir að Helgi hafi trúlega keypt bókina.

Jón diz que Helgi tem provavelmente comprado o livro (Thráinsson, 1986, p. 171)

As línguas simétricas exibem o efeito V2 irrestritamente em qualquer tipo de oração subordinada, o que contrasta com as línguas assimétricas, que, quando exibem o efeito V2 em oraçóes subordinadas, apresentam uma serie de restriçóes?.

7 Durante muito tempo, foi proposto que as línguas escandinavas só exibiam o efeito V2 em completivas de verbos-ponte (dizer, pensar, argumentar etc). Contudo, Julien (2010) mostra que o 
Diante desse quadro, uma série de estudos (Thráinsson, 1986; Santorini, 1989, 1995; Diesing, 1990 entre outros) propôs que o movimento do verbo nas línguas simétricas é diferente do movimento do verbo nas línguas assimétricas, sendo que, nas simétricas, o verbo se moveria apenas até I, com SpecIP podendo funcionar como uma posição A-Barra que abriga o elemento pré-verbal. Essa proposta é representada de forma adaptada em (9) a seguir (compare-se (9) com (6) acima):

(9)

a. Oraçóes matrizes

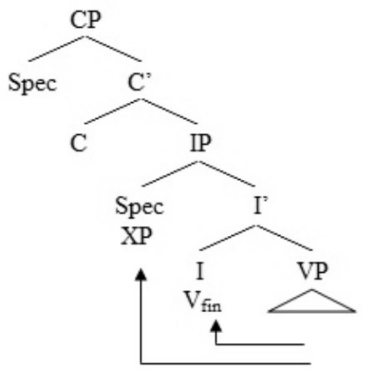

b. Oraçôes subordinadas

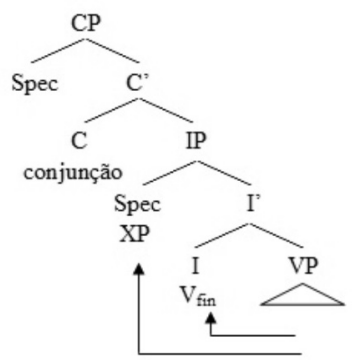

Entretanto, Vikner (1995) questiona se realmente as línguas V2 simétricas apresentam movimento do verbo para uma posição mais baixa, em contraste à análise padrão proposta para as línguas V2 assimétricas. Por exemplo, o autor mostra que, em geral, nada impede a adjunção de um elemento adverbial à categoria IP, ao passo que adjunção à categoria $\mathrm{CP}$ não é aceitável. Os exemplos do alemão, apresentados a seguir, ilustram essa restrição a respeito da adjunção de constituintes adverbiais.

(10) a. ${ }^{*}$ Tatsächlich dieses Buch hat der Junge gelesen Realmente este livro tem o menino lido

b. Dieses Buch hat tatsächlich der Junge gelesen Vikner, 1995, p. 103)

Em (10a), ante a hipótese de que a posição imediatamente pré-verbal em alemão é SpecCP (trata-se de uma língua assimétrica), deve-se pressupor que o advérbio foi adjungido à categoria CP. Já em (10b), assumindo-se que o sujeito pós-verbal está em SpecIP, supóe-se que o advérbio foi adjungido à projeção IP, considerando que tal elemento se encontra estruturalmente abaixo do verbo alçado para o núcleo $\mathrm{C}$.

efeito V2 nessas línguas está relacionado com força ilocucionária. 
Vikner (1995) argumenta que, caso a impossibilidade de adjunção à projeção CP seja uma restrição universal e não apenas específica do alemão, é possível testar se, em línguas V2 simétricas, a posição para onde o XP pré-verbal se move é de fato SpecIP ou não. A ideia é que, se a posição pré-verbal realmente for SpecIP, elementos adverbiais poderão preceder o XP imediatamente pré-verbal, já que isso seria um caso de adjunção à categoria IP. Por outro lado, se a posição pré-verbal de línguas V2 simétricas não for SpecIP, mas sim SpecCP, como nas línguas assimétricas, constituintes adverbiais não poderão preceder o XP imediatamente pré-verbal, já que isso seria, em termos estruturais, um caso de adjunção à projeção $\mathrm{CP}$. No iídiche, uma típica língua V2 simétrica, tem-se um padrão absolutamente idêntico ao que é observado no alemão, como em (11):

(11) a. ${ }^{*}$ Leyder dos bukh hot dos yingl geleyent Infelizmente este livro tem o menino lido

b. Dos bukh hot leyder dos yingl geleyent (Vikner, 1995, p. 106)

Para Vikner (1995), o que há nas línguas V2 simétricas é a possibilidade de recomplementação de $\mathrm{CP}$ (isto é, a presença de duas projeçôes $\mathrm{CP}^{8}$ ). No caso das oraçóes subordinadas com ordem linear V2, o complementizador seria concatenado no núcleo de uma categoria $\mathrm{CP}$ mais alta, ao passo que o verbo e o $\mathrm{XP}$ pré-verbal ocupariam, respectivamente, o núcleo e o especificador de um $\mathrm{CP}$ mais baixo. Ou seja, tanto línguas assimétricas quanto línguas simétricas formariam a ordem V2 na periferia da sentença. A única diferença é que as línguas V2 simétricas permitiriam a projeção de um duplo CP, resultando, portanto, no licenciamento de oraçóes subordinadas com a sequência linear V2. No que se segue, reinterpretaremos a proposta de Vikner (1995) dentro de uma abordagem cartográfica da periferia da sentença.

\subsubsection{Efeito V2 e traço EPP}

A partir da proposta cartográfica (Rizzi, 1997 e trabalhos subsequentes), Roberts (2004) propóe que o efeito V2 nas línguas germânicas assimétricas seria o resultado de quatro requerimentos:

(12) a. movimento do verbo para Fin.

b. movimento de um XP pra SpecFinP

8 Baseando-se em (6a), é como se o CP contendo o XP e o verbo fosse dominado por outro CP contendo a conjunção.

Pinto CF, Antonelli AL. O Efeito V2 na história do espanhol e português europeus 
c. restrição de somente um XP.

d. assimetria oração matriz/oração subordinada. (Roberts, 2004, p. 315)

O requerimento (a) seria decorrente de uma propriedade paramétrica determinando que Fin[+finito] de línguas V2 apresente uma realização fonológica, o que atrairia o verbo para Fin em oraçóes matrizes, por exemplo. O requerimento (b) é explicado da seguinte forma: se a restriçẫo fonológica de Fin é satisfeita via movimento do verbo, a posição SpecFinP é dotada de um traço EPP que exige o movimento de um constituinte para essa posição". Quanto ao requerimento (c), a restrição de um único constituinte se deve ao fato de que, como o XP em SpecFinP não tem nenhum traço específico, mas foi movido para satisfazer o traço EPP dessa posição, por razões de minimalidade relativizada, o seu movimento bloqueia o movimento de qualquer outro elemento para qualquer posição acima de Fin. Por fim, com relação à propriedade (d), que diz respeito à assimetria matriz/subordinada, isso ocorreria porque, nas subordinadas, o complementizador é quem satisfaz o requerimento fonológico de Fin, impedindo o movimento do verbo finito.

Tendo em conta a proposta de Julien (2010), de que o efeito V2 está relacionado com força ilocucionária, Pinto (2011) considera que uma explicação do efeito V2 somente a partir dos traços de Fin não é suficiente. Assim, se propõe, ao contrário de Roberts (2004), que as oraçôes matrizes são dominadas pela projeção Force $\mathrm{P}^{10}$ e que o efeito $\mathrm{V} 2$ é resultado de um parâmetro: se uma língua é parametrizada como [+V2], o movimento do verbo para CP é determinado pelo conjunto de traços [ \pm selecionado; \pm declarativo; \pm assertivo] nos núcleos Force matriz e subordinado. $\mathrm{O}$ efeito $\mathrm{V} 2$ nas oraçóes matrizes é bastante parecido nas línguas assimétricas e simétricas. A variação se dá exclusivamente nas oraçôes subordinadas.

O núcleo Force das oraçôes matrizes é composto invariavelmente pelos traços [-selecionado; +declarativo; +assertivo].$^{11} \mathrm{O}$ traço [+assertivo] faz com que

9 Uma evidência de que o movimento do verbo é o que desencadeia o movimento do XP é encontrada no fato de que não há movimento de XP quando Fin* é realizado pela conjunção. Nada impede, a priori, que esse movimento seja realizado já que são possíveis perguntas subordinadas clivadas: "ele perguntou que livro que você leu ontem".

10 A exposição de Demonte e Fernández-Soriano (2009) também dá evidências empíricas para se postular, conforme Rizzi (1997) e contrariamente a Roberts (2004), que ForceP existe em oraçóes declarativas matrizes. Assumimos assim um CP complexo cuja projeção dominante é ForceP mesmo em orações declarativas matrizes.

11 O traço [+assertivo] se deve ao fato de que as orações matrizes contêm a ilocução primária da estrutura.

Pinto CF, Antonelli AL. O Efeito V2 na história do espanhol e português europeus 
Force selecione FinP*, no sentido de Roberts (2004) e tanto o verbo como um $\mathrm{XP}$ qualquer se movem para FinP. ${ }^{12}$

O núcleo Force das oraçôes subordinadas está aberto à variação. Quando Force tem os traços [+selecionado; +declarativo; +assertivo], têm-se oraçóes subordinadas V2. Como Force é [+selecionado], é preenchido pela conjunção e o verbo se move para Fin. Quando Force tem os traços [+selecionado; +declarativo; -assertivo], têm-se oraçóes subordinadas não-V2. As línguas V2 simétricas atribuiriam invariavelmente o traço [+assertivo] ao CP subordinado.

Partindo da ideia de que a ordem V2 sempre é formada na periferia da sentença (cf. Vikner, 1995) e seguindo a proposta inicial de Roberts (2004), a análise de Pinto (2011) explica através de uma visão cartográfica a variação na manifestaçáo do efeito V2. Todas as línguas teriam as mesmas projeçóes funcionais e o que seria variável são as propriedades, ou seja, os traços, de cada projeção funcional em cada língua. Como o CP é um campo (e não uma única projeção) nessa visão, o argumento de movimento do verbo diferenciado em línguas simétricas e assimétricas devido à falta de posição no CP subordinado (que já estaria preenchido pela conjunção) perde força ${ }^{13}$.

12 Pinto (2011) propóe que o lugar de pouso para o verbo é diferente no CP matriz de línguas V2 rígidas e línguas V2 mais flexíveis. Parece que o efeito V2 de línguas V2 rígidas é realizado em ForceP, enquanto que o efeito V2 de línguas mais flexíveis é realizado em FinP. Por exemplo, em oraçóes matrizes o alemão exibe construçóes com ordem V3 em contextos muito raros; por outro lado, as línguas escandinavas e as línguas V2 simétricas exibem ordem V1 narrativa e construçóes de object shift. Hinterhölzl e Petrova (2010) discutem a mudança linguística da ordem V1 para a ordem V2 na história do alemão e propóem que a posição para a qual o verbo se move é a mais alta da sentença, ou seja, Force. Essa proposta explica, ademais, a semelhança entre oraçóes matrizes e subordinadas com relação a diversos fenômenos (ver Den Besten, 1989).

13 Em Rivero (1980) já se apresenta uma evidência de que o CP pode ser compreendido como um campo e não como uma única projeção funcional. Veja-se o contraste entre (i) e (ii) abaixo:

(i) a. * ¿Qué te pregunta (que) por qué no tiene?

b. ${ }^{*}$ ¿Qué preguntan (que) quién tiene?

(ii) a. Dinero, te pregunta (que) por qué no tiene.

b. Dinero, preguntan (que) quién tiene. (Rivero, 1980, p. 380)

Rivero (1980) argumenta que as sentenças em (ii), diferentemente de construçóes como "Dinero, no lo tengo", são geradas via movimento. Se o CP fosse constituído por apenas uma projeção, os exemplos em (ii) deveriam ser agramaticais, como os exemplos em (i) tendo em vista que, como o CP subordinado já está ocupado por um elemento, o XP fronteado no $\mathrm{CP}$ matriz não teria posição de escape para extração. Como os exemplos em (ii) são gramaticais, Rivero (1980) conclui que o CP tem outra posição, diferente da posição ocupada por elementos-wh, pela qual é possível fazer extraçáo para oraçóes matrizes. 


\section{A PERDA DO EFEITO V2 NA HISTÓRIA DO ESPANHOL}

\subsection{Questóes empíricas}

Fontana (1993), ao estudar a mudança na ordem de palavras e estrutura dos clíticos na história do espanhol, propôs que o espanhol antigo, diferentemente do espanhol atual, se comportava como uma língua simétrica da mesma forma que o iídiche ou o islandês atuais. Dados como os ilustrados em (13) a seguir mostram essa propriedade do espanhol antigo:

(13) a. Este logar mostro dios a abraam.

Este lugar mostrou Deus a Abraáo

b. Quando esto oyo el Rey [...]

Quando isto ouviu o Rei... (Fontana, 1993, p. 64/72)

Por outro lado, ao considerar a ordem V-S, como nos exemplos em (14):

(14) a. A menudo juegan niños en este parque.

b. Todos los días compra Juan el diario. (Zubizarreta, 1998, p. 100/109)

Zubizarreta (1998) propóe que o espanhol moderno tenha a mesma estrutura gramatical que o espanhol antigo, comportando-se ainda como uma língua V2. Neste mesmo sentido, Fernández-Ordóñez (2009) argumenta que o espanhol antigo e o espanhol moderno se comportam da mesma maneira com relação à topicalização e à focalização e o uso de clíticos $^{14} \mathrm{e}$, portanto, teriam a mesma estrutura ${ }^{15}$.

14 Resumindo: o espanhol atual só possui clíticos para objetos diretos e indiretos, diferentemente do catalão, que possui clíticos para outras funções sintáticas (ver Hernanz e Brucart, 1987). Quando o objeto fronteado é um tópico, a retomada com o clítico é obrigatória. Quando o objeto fronteado é um foco, não há retomada com clítico:

(i) (Respecto del) El libro, Pedro lo leyó anoche.

(ii) EL LIBRO leyó Pedro anoche (y no la revista).

15 Mensching (2009) e Pinto (2010) mostram que as construçóes de deslocamento à esquerda clítica já existiam no espanhol antigo. Contudo, variavam com as construções V2 sem clítico. A partir desses dados, no capítulo 2 de Pinto (2011) se sugere a existência de um processo de competição de gramáticas no sentido de Kroch (2001). Tal competição de gramáticas é decorrente de um processo de transmissão linguística irregular a partir do contato com os povos germânicos. 
No entanto, Fontana (1993) mostra algumas diferenças na ordenação dos constituintes no espanhol antigo e no espanhol moderno (tais como a possibilidade de ordem $\mathrm{O}-\mathrm{V}$ sem duplicação pelo clítico e a flexibilidade de fronteamento no espanhol antigo - fenômenos inexistentes no espanhol moderno ${ }^{16}$ ), o que evidencia que as duas fases do espanhol não têm a mesma estrutura. ${ }^{17}$ Pinto (2011) acrescenta ainda outras diferenças: a possibilidade de construçóes de object shift e a maior liberdade de elementos intervindo nos complexos verbais (locuçóes e tempos compostos) no espanhol antigo.

Assumimos a proposta de Fontana (1993), de que as duas fases do espanhol não possuem a mesma estrutura, ou seja, não são a mesma gramática. Os dados a seguir confirmam que o espanhol antigo era uma língua V2 simétrica, como propôs Fontana (1993) $)^{18}$. Os exemplos em (15) a (18), de Pinto (2011, p. 255), ilustram as características que são encontradas para definir o espanhol antigo como uma língua $\mathrm{V} 2^{19}$ :

(15) a. aqui comienza el libro de la flor de las historias de oriente

b. como agora fezieron el maestre don Pero Núnnez

(16) a. E esta carta otorga la abatíssima Sancha Garcíez, e la priora doña María Fortúnez e tod el convento.

b. si corazon has.

16 Hernanz e Brucart (1987) mostram que, na tematização, o espanhol moderno não pode frontear determinados tipos de elementos/complementos verbais, ao contrário da focalização, que não impóe restriçóes quanto ao tipo/função do constituinte fronteado. No capítulo 3 de Pinto (2011), essa diferença é explicada a partir da noção de operador, proposta por Cinque (1995).

17 É interessante observar que Zubizarreta (1998) discute as diferenças apresentadas por Fontana (1993) e mesmo assim propóe que o espanhol antigo e o espanhol atual tenham a mesma estrutura. 18 Há ordens de constituintes possíveis em ambas as fases. Kroch (2001) ressalta que gramáticas diferentes (língua-I) podem gerar os mesmos dados (língua-E). Desta forma, nos deteremos na apresentação e discussão dos dados (língua-E) que evidenciam que as gramáticas (língua-I) são diferentes. Ver Pinto (2011), onde se faz, um debate sobre os aspectos que podem ou não distinguir as duas fases da língua além dos casos que aparentemente parecem ser uma exceção à gramática V2. 19 Os dados do espanhol foram coletados a partir do Corpus Diacrónico del Español (CORDE), da Real Academia Espańola e por um conjunto de textos editados cedidos pelo Prof. Dr. Josep María Fontana, da Universitad Pompeu Fabra. Uma diferença substancial entre a organização do CORDE e o corpus Tycho Brahe (este último será apresentado posteriormente quando discutirmos a perda do efeito V2 no português) é que, no primeiro, os textos estão organizados pela data de produçáo e, no segundo, os textos estão organizados pela data de nascimento dos autores. 
(17) a. a dios debe hombre adelantar y poner primeramientre. en todos los buenos hechos que quisiere comenzar.

b. que no puede mi paciencia tolerar que haya subido en corazón humano conmigo en el ilícito amor comunicar su deleite.

(18) a. si el deudor otros bienes tuviese

b. porque este cuerpo muchas lágrimas ha dejado a sus parientes: y amargos dolores.

Os exemplos em (15) ilustram a ordem V2 em oração matriz e oração subordinada; os exemplos em (16) ilustram a ordem O-V sem retomada clítica em oraçáo matriz e oração subordinada; os dados em (17) ilustram a ordem Aux-S-V; os dados em (18) ilustram construçóes de object shif ${ }^{0}$. O conjunto de dados em (15) a (18) oferecem evidências de que o verbo, no espanhol antigo, se movia para $\mathrm{CP}$, diferentemente do espanhol atual, que exibe movimento do verbo exclusivamente para IP.

Em adição a esses dados, pode ser acrescentado o comportamento dos pronomes complementos. No espanhol atual, os pronomes tônicos ("mí", "ti" etc.), quer em posição pré ou pós-verbal, devem ser retomados pela forma átona equivalente; no espanhol antigo, as formas tônicas podiam aparecer sem a duplicação, independentemente da posição em que estivessem ${ }^{21}$.

Com relação à ordem O-V e à retomada clítica, Pinto (2011, p. 256-257) mostra que não havia um comportamento semelhante ao espanhol atual conforme advoga Fernández Ordónez (2009). Os dados apresentados mostraram contextualmente que não havia duplicação tanto nos casos em que o objeto fronteado era um tópico/tema ou um elemento neutro. Os casos de focalização não foram analisados já que são irrelevantes para a discussão tendo em vista que, no espanhol atual, tampouco, exibem a retomada pelo clítico. No caso da ordem $\mathrm{O}-\mathrm{V}$ com o objeto tendo uma função informativa neutra, no espanhol atual a única opção é a ordem V-O, o que mostra que o espanhol antigo tinha um

20 Bobaljik e Jonas (1996) estudam essas construções no islandês, porém propóem que o verbo esteja em IP. Em Pinto (2011) se faz uma reinterpretação dessas construçôes dentro de um modelo em que o verbo está em CP nas línguas V2.

21 São encontrados também dados bem interessantes como partes de sintagmas nominais e elementos de coordenação fronteadas deixando o resto do sintagma em posição pós-verbal. É interessante observar também que, no mesmo texto, se encontram as duas variantes: uma com todo o sintagma movido e outra com somente parte dele:

(i) Quebrantamiento es de casa. / et quebrantamiento de casa es.

(ii) Guysado es e razon que... (Pinto, 2011, pp. 88-89)

Pinto CF, Antonelli AL. O Efeito V2 na história do espanhol e português europeus 
comportamento V2. Desta forma, Pinto (2011, p. 212) sintetiza a seguinte correlação entre as duas fases da língua:

\section{(19) Contexto}

Focalização

Tematização

Neutro

$\begin{array}{cc}\text { Espanhol antigo } & \text { Espanhol atual } \\ \text { O-V } & \text { O-V } \\ \text { O-V } & \text { O-cl-V } \\ \text { O-V } & \text { V-O }\end{array}$

\subsection{A mudança linguística}

A ideia central dos estudos diacrônicos dentro do quadro gerativista é que a aquisição da linguagem é o lugar em que a mudança linguística acontece através da fixação de parâmetros de forma diferente da geração anterior. De acordo com a Teoria de Princípios e Parâmetros (Chomsky, 1981, 1986) especificamente, a aquisição da linguagem é explicada através da relação entre faculdade da linguagem e o input (os dados linguísticos primários) aos quais a criança é exposta. Se a criança fixa os parâmetros de acordo com a fixação da geração anterior, a língua permanece estável. Caso contrário, a língua muda. Para Lightfoot (1979, 1991, 1998, 2006), para que a fixação de parâmetros seja correta ${ }^{22}$, é necessário que o aprendiz tenha pistas no input para fixar um valor do determinado parâmetro. Quando não encontra essas pistas, segundo Roberts e Roussou (2003), a criança segue um "mecanismo de segurança" e fixa uma opção default.

Roberts (2007) pontua que as pistas do input podem ficar obscurecidas tanto por fatores internos como por fatores externos. Entendemos os fatores internos como alguma erosão fonológica, a náo produção de um determinado dado etc. Como fatores externos, podem ser considerados, entre outras coisas, o contato de línguas e as situaçóes de bilinguismo (Kroch, 2001) ${ }^{23}$.

22 Este ponto é matizado por Roberts e Roussou (2003: 13). Se "fixação correta de parâmetros" significar fixar os parâmetros de modo que a gramática convergente seja idêntica à gramática adulta, há uma contradição entre o problema lógico da mudança linguística e o problema lógico da aquisição da linguagem, porque a previsão que se faz é a de que as línguas não mudariam nunca. Roberts e Roussou (2003) propóem então que a aquisição da linguagem seja um processo "fracamente determinístico", ou seja, a criança deve fixar os parâmetros de forma consistente com o input e não com a gramática adulta. Os autores salientam, no entanto, que, quase sempre, há convergência com a gramática adulta.

23 Os fatores internos podem existir sem a necessidade da atuação de um fator externo. Contudo, os fatores externos sempre provocam a atuação de fatores internos. E por essa razão mesma é que a língua muda por causa de contatos linguísticos. 
Com relação à perda do efeito V2 no espanhol, Fontana (1993) comenta que, no século XV, as construçóes com objeto fronteado sem retomada clítica começam a desaparecer e as construçóes de deslocamento à esquerda clítica começam a aumentar, culminando numa mudança de gramática. $\mathrm{O}$ autor, contudo, não discute as causas da mudança de uma gramática V2 para uma gramática não V2.

Pinto (2011) retoma a tese de Fontana (1993) e procura explicar, a partir da proposta de Lightfoot $(1979,1991,1998,2006)$, o que teria causado a perda do efeito V2 no espanhol ${ }^{24}$. Embora o espanhol antigo e o espanhol moderno apresentem muitas diferenças sintáticas, as únicas características que evidentemente distinguem as duas fases como V2 e não V2 respectivamente são aquelas apontadas de (15) a (18). Em termos quantitativos, o número de elementos em posição pré-verbal não é um diferenciador das duas fases, já que a porcentagem de ordem V1, V2 e V>2 se mantém constante em todos os períodos ${ }^{25}$.

Desta forma, para que houvesse uma mudança de gramática, os aprendizes deveriam perder o acesso a essas construçóes que caracterizavam o espanhol como uma língua V2. Considerando o caso dos objetos fronteados, cujos dados são bastante robustos, a tabela 1 a seguir mostra um decréscimo de objetos sem retomada clítica entre os séculos XIV e XVI:

Tabela 1. Objetos com clítico versus sem clíticos em primeira posição entre os Séculos XII e XVI

\begin{tabular}{|l|c|c|c|c|}
\hline \multirow{2}{*}{} & \multicolumn{2}{|c|}{ Com clítico } & \multicolumn{2}{c|}{ Sem clítico } \\
\cline { 2 - 5 } & ocorrências & porcentagem & ocorrências & porcentagem \\
\hline Século XII & 7 & 25,00 & 21 & 75,00 \\
\hline Século XIII & 7 & 18,44 & 31 & 81,56 \\
\hline Século XIV & 2 & 16,67 & 25 & 83,33 \\
\hline Século XV & 4 & 12,50 & 28 & 87,50 \\
\hline Século XVI & 5 & 33,33 & 10 & 66,67 \\
\hline Século XVII & 5 & 45,46 & 6 & 54,54 \\
\hline
\end{tabular}

24 Apresentamos aqui somente a proposta de explicação do autor. Contudo, em Pinto (2011) se faz uma discussão de outras propostas, como a de Fernández-Ordóńez (2009), que propóe que a perda do efeito V2 é decorrente do aumento da focalização do sujeito em posição pré-verbal, hipótese que é negada por Pinto (2011), considerando que a proporção da ordem S-V e V-S se mantém estável ao longo dos séculos.

25 Ao longo dos séculos, a média é a seguinte: V1 = 50\%; V2 = 45\%; V3 = 5\%. 
A Tabela 1 mostra que, até o século XV, ainda havia evidência para a aquisição de uma gramática $\mathrm{V} 2$ dada a alta frequência de construções com objeto deslocado sem retomada clítica. No século XVI, no entanto, a porcentagem de objeto sem retomada é bastante baixa em relação ao período anterior ${ }^{26} \mathrm{e}$, em adição, os dados passam a ser obscurecidos pelo aumento considerável de outros tipos de objeto que não possuem clíticos correspondentes em primeira posição ${ }^{27}$.

Segundo a proposta de Pinto (2011), a mudança teve três passos. Passo 1: uma gramática V2 com bastante fronteamento de objetos sem retomada clítica; Passo 2: uma gramática V2 com pouco fronteamento de objetos sem retomada clítica; Passo 3: uma gramática não-V2 em decorrência da falta de pistas para aquisição de uma gramática V2 (ausência total de objetos fronteados sem retomada clítica).

A análise proposta é confirmada pelos dados em (20) a seguir, que mostram essa mudança a partir de um mesmo verbo e no mesmo contexto sintático:

(20) a. e de todos los derechos que a ellas perteneçen, (1303)

b. reparar et fazer todo reparamiento et fortifficamiento que al dicto muro pertenesce enla endrecha dela dicta su casa... (1381)

c. que yo aya o me pertenesca aver (1467)

d. con todo lo que a la dicha casa le pertenece, (1593) (Pinto, 2011, p. 288)

Como se pode ver, no século XIV, o objeto podia ser fronteado sem a retomada clítica como nos exemplos (20a) e (20b). No século XV, como mostra (20c), o verbo aparece somente com o clítico. No exemplo (20d), o objeto fronteado aparece duplicado pelo pronome clítico.

Kroch (2001) comenta que a perda do efeito V2 no inglês está relacionada com contato de línguas entre as variedades do norte e do sul, sendo que uma tinha uma gramática V2 e outra, não. No caso do espanhol, por outro lado, acreditamos, em primeira instância, que o contato de línguas durante o período da Reconquista, por exemplo, não tenha causado por si só uma mudança gramatical neste sentido porque, conforme argumenta Pinto (2011), se o efeito V2 no espanhol (e nas línguas românicas como um todo) é uma influência do contato

26 Esse processo parece ser acentuado pela já existência no espanhol antigo de construçóes de deslocamento à esquerda clítico. Os dados da Tabela 1 mostram que as construçôes de deslocamento à esquerda clítico se mantêm constantes no período.

27 O estatuto do objeto em primeira posição precisa ser estudado com mais detalhes já que em Pinto (2011) só se comprovou que o objeto poderia ser fronteado independentemente de seu estatuto informativo.

Pinto CF, Antonelli AL. O Efeito V2 na história do espanhol e português europeus 


\section{linguístico com os povos germânicos $28-29$ e como os povos germânicos ocuparam}

28 Este aspecto parecer não ser muito aceito pela Linguística Hispânica, inclusive por pesquisadores atuais. Uma versão do texto foi apresentada em um evento e um parecerista disse:

Lo que en cambio carece de fuerza de convicción son resultados que se infieren sin que estén basados en un análisis: se parte del supuesto de que V2 en las lenguas iberorrománicas medievales deriva de la influencia germánica. Esta no se investiga ni se aportan datos a que haya podido haber tal influencie (de hecho, la influencia de los pueblos germánicos sobre las lenguas peninsulares es, como sabemos, muy escasa. Los Visigodos, el pueblo que más tiempo tuvo de ejercer su influjo, llegaron a la Península por lo que parece plenamente latinizados y no aportaron más que sus antropónimos y algún topónimo).

Pinto (2011) faz uma discussão da questão trazendo referências de que esta hipótese amplamente assumida na Linguística Hispânica parece estar equivocada. O estudo de Tuten (2003) mostra que os francos tiveram uma forte influência na Península Ibérica por volta do século XIII; Kremer (1982) dá evidências socio-demográficas e linguísticas de que a influência germânica, em especial dos francos, não parece ter sido pouca. O trabalho de Chirita (2003) mostra que o latim já exibia um caráter V2. Muito questionável é a visão da tradição linguística espanhola em acreditar que os povos germânicos chegaram à Península Ibérica plenamente latinizados. O trabalho de Guerras (1995) deixa claro que o contato entre romanos e germanos é bastante antigo e que desde muito cedo havia convivência entre os dois grupos em várias partes do Império Romano. Por fim, mais questionável ainda é a visão de que, se dois grupos entram em contato, somente um influencia o outro. Esquece-se de que quando os germanos aprendiam a falar latim, esse latim era germanizado de alguma forma. Guerras (1995, p. 79) diz: "[os germanos] Antes, pelo contrário, o respeitaram, estabeleceram pactos de federação, se integraram primeiro no exército, depois na totalidade da vida do Império. Romanizaram-se ao mesmo tempo que ocorreria a germanização dos romanos". Assim, a influência dos povos germanos sobre o espanhol, em primeira instância, parece não ter sido direta, mas via latim. No século XIII, com a descida dos francos, tais características podem ter sido acentuadas ou, pelo menos, mantidas.

29 Pinto (2011) recorre ao trabalho de Hinterhölzl e Petrova (2010) para mostrar que o efeito V2 do espanhol antigo é decorrente de um processo de transmissão linguística irregular que aconteceu na época das invasóes bárbaras. 
toda a Península Ibérica antes da chegada dos povos árabes, se supóe que mesmo no sul os dialetos românicos já possuiriam uma gramática V2 ${ }^{30-31}$.

Em síntese, a proposta de Pinto (2011) procura explicar as causas da perda do efeito V2 no espanhol antigo, questão que não foi abordada em Fontana (1993). A explicação é encontrada na falta de evidências aos aprendizes dos séculos XV e XVI para fixar os parâmetros de uma gramática V2. E, dentro dessa proposta, as únicas evidências concretas que os aprendizes dispunham de que sua gramática era uma gramática V2 era a possibilidade de fronteamento de objetos sem retomada clítica, o fronteamento de fragmentos de constituintes e a possibilidade da ordem Aux-S-V. Quando os aprendizes não encontram de maneira robusta esses dados no input, acontece a mudança gramatical ${ }^{32}$.

\subsection{A diferença estrutural das duas fases do espanhol}

Embora Pinto (2011) assuma boa parte da proposta de Fontana (1993), há uma divergência estrutural na explicação do efeito V2 do espanhol antigo nas duas propostas. Fontana (1993) assume que no espanhol antigo o verbo realizava o mesmo movimento que nas línguas V2 simétricas atuais. Como discutido na seção 2.1.2, em algumas análises foi proposto que, nessas línguas, o verbo se moveria apenas até IP, cujo especificador seria uma posição sincrética (A e A-Barra

30 Observe-se que, durante o século VIII, os árabes conseguem isolar os hispano-godos nas montanhas do norte. Até entre os séculos XII e XIII, a população hispano-goda consegue recuperar boa parte da Península. Neste momento, chegam os francos, que parecem reforçar o efeito V2 no espanhol. Com relação aos árabes, Pinto (2011) sugere que tenham influenciado na manutenção da ordem V-S no espanhol. Observe-se que o francês exibia a ordem V-S quando era uma língua V2. Quando perde o efeito V2, o francês também perde a ordem V-S, fato que não acontece com o espanhol. Resta saber como era a sintaxe da posição do sujeito nessas línguas árabes quando essas populaçôes migraram para a Península Ibérica.

31 Desta forma, acreditamos que a Reconquista não exerceu nenhum papel fundamental na perda do efeito V2 na história do espanhol uma vez que tanto a variedade dominante como as demais variedades peninsulares tinham um caráter V2. Este aspecto difere a perda do efeito V2 na história do espanhol da perda do efeito V2 na história do inglês. Kroch (2001) destaca que a perda do efeito V2 na história do inglês foi causada justamente pelo contato de dialetos, uma vez que um dialeto V2 entrou em contato com outro dialeto não V2. Assumimos que este não é o caso do espanhol.

32 Ilza Ribeiro, em comunicação pessoal, comenta que essa diminuição na frequência dos dados pode ser o resultado da mudança e não a causa dela. Os trabalhos de Ribeiro e Torres Morais (2009) e Ribeiro (2012) estudam as construçóes subordinadas com "duplo que" no português antigo (no espanhol antigo também havia esse tipo de construção conforme sinalizam Fernández-Ordóñez, 2009, e Pinto, 2011). Nesses casos, o verbo era impossibilitado de se mover para CP. Talvez, este tenha sido, conforme comenta Ilza Ribeiro, o gatilho para a mudança sintática.

Pinto CF, Antonelli AL. O Efeito V2 na história do espanhol e português europeus 
ao mesmo tempo), o que permitiria que qualquer constituinte fosse fronteado para esta posição. Assim, no modelo de Fontana (1993), a diferença estrutural entre as duas fases da língua se restringiria às características da posição SpecIP, que passaria de uma posição sincrética, no espanhol antigo, para uma posição-A, no espanhol atual.

A partir da discussão em 2.1.3, na qual é proposta uma análise unificada para o efeito V2 tanto em línguas simétricas como em assimétricas, Pinto (2011) propóe, diferentemente de Fontana (1993), que, no espanhol antigo, o verbo se movia para uma posição mais alta, a saber, Fin*. Desta forma, a diferença entre as duas fases da língua estaria relacionada com diferentes movimentos de verbo. No espanhol antigo, o verbo fazia generalizadamente (em todos os tipos de oraçóes) o movimento V-to-I-to-C. O sujeito se movia categoricamente para SpecIP e um constituinte qualquer se movia para SpecFinP. A ordem S-V era decorrente, portanto, do movimento do verbo e do sujeito para CP. No espanhol moderno, o verbo faz somente o movimento V-to-I. ${ }^{33}$ De acordo com Pinto $(2011)^{34}$, a posição do sujeito referencial pré-verbal no espanhol moderno é SpecIP. Como não há nenhum traço EPP que force movimento de algum constituinte generalizadamente para CP, a ordem S-V é decorrente do movimento do verbo e do sujeito até $\mathrm{IP}^{35}$.

33 Suñer (1994) propõe que em nenhum tipo de oração haja movimento V-to-I-to-C no espanhol moderno. Um dos argumentos é o contraste entre o espanhol e o inglês com relação à possibilidade de advérbios intervindo entre o elemento interrogativo e o verbo. Pinto (2011) assume esta análise. 34 Pinto (2011) discute principalmente a proposta de Olarrea (1997), que classifica os sujeitos em três tipos diferentes (referenciais, não referenciais e negativos) e propóe que cada um deles ocupa uma posição estrutural diferente. Pinto (2011) concorda com a diferença estrutural entre os três tipos de sujeito, porém argumenta, seguindo o trabalho de Costa (2001) para o português europeu, que o sujeito referencial pré-verbal no espanhol moderno não está necessariamente deslocado à esquerda. Assim como o objeto, o sujeito pode estar deslocado à esquerda ou não.

$35 \mathrm{Na}$ análise de Rivero (1992), o que diferencia as duas fases são as possibilidades de adjunção (a XP e a X') em cada fase. Contudo, seguindo o modelo cartográfico de Rizzi (1997) e Cinque e Rizzi (2008), todas as línguas teriam o mesmo inventário de projeçóes funcionais na faculdade da linguagem e o que as diferenciaria seriam os traços dos itens lexicais, conforme propóe Chomsky (1995). Pinto (2011) apresenta evidências contra a análise de múltiplos especificadores com base no ordenamento de sujeitos, advérbios e objetos no espanhol atual e reinterpreta a ordem S-O-V, das construçôes de object shift, como movimento de constituintes para CP (S em SpecFrameP; O em SpecFinP; V em Fino). Na análise de Rivero (1992), S está em SpecIP, O em adjunção à I', e V em Io. De todos os modos, essas divergências parecem estar mais relacionadas com opçóes teóricas diferentes do que com análises divergentes dentro do mesmo marco teórico. 


\section{A PERDA DO EFEITO V2 NA HISTÓRIA DO PORTUGUÊS}

\subsection{Sobre o efeito V2 na história do português}

Um ponto que parece não ser controverso em relação ao português atual diz respeito à sua natureza não-V2. De fato, ao contrário de línguas V2 prototípicas, o português não licencia necessariamente inversão do sujeito nos casos em que um constituinte diferente do sujeito é superficializado em posição pré-verbal, como mostram os exemplos em (21) extraídos de Costa (1998, p. 111/117).

(21) a. Com a Maria, o Pedro falou.

b. A sopa, o cão comeu.

Entretanto, diversos trabalhos sobre a evolução gramatical do português defendem que, em estágios passados, essa língua manifestava características de um sistema V2 (Ribeiro, 1995; Torres Morais, 1993; Galves, 1997; Gibrail, 2010; Antonelli, 2011). Ribeiro (1995) caracteriza o português antigo como um sistema gramatical em que, nas sentenças raízes, o verbo se aloja no núcleo funcional $\mathrm{C}$, à semelhança de línguas V2 como o alemão. Os casos de ordem XP-V-S nessa fase do português, isto é, sentenças com ordem linear V2 que manifestam inversão do sujeito, como exemplificado em (22), seriam o resultado de fronteamento de um complemento verbal ou de um elemento adverbial para o início da sentença, precisamente para a posição de especificador da projeção cujo núcleo hospedaria o verbo finito, a saber, SpecCP.

(22) a. E esto lhi fazia o prazer que avia em cuidar sempre nas cousas celestiaes

b. E esta vertude de paceença ouve este santo monge Libertino mui compridamente

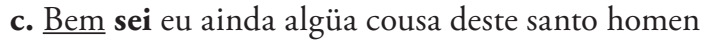

d. E aacima a piedade venceu a homildade (Ribeiro, 1995, p. 100)

Ribeiro (1995) aponta também que diferentes tipos de constituintes podem ser fronteados de uma sentença encaixada para o domínio da oração matriz, desencadeando a inversão V-S. Em (23), o sintagma nominal sujeito da sentença encaixada é fronteado para a oração matriz e o que se vê é o sujeito da oração matriz aparecendo posposto ao verbo finito.

(23) Padre, [aqueste por que me tu rogas] $]_{\mathrm{i}}$ vejo eu que $\mathrm{t}_{\mathrm{i}}$ non he monge (Ribeiro, 1995, p. 159) 
Em (24), o elemento deslocado da oração encaixada é o sintagma nominal objeto. Nesse exemplo, tal como em (23), a oração matriz também manifesta inversão verbo-sujeito.

(24) E [estes $]_{i}$ dizia el-rrei que mandava matar $t_{i}$ porque [...] (Ribeiro, 1995, p. 159)

A autora destaca que o padráo de inversáo verbo-sujeito de exemplos como (23) e (24) é típicos de operações de movimento envolvendo o sistema CP, como o caso de fronteamento de sintagmas wh. Em vista disso, Ribeiro argumenta que, em todos esses exemplos, tem-se o verbo da oração matriz em C e um constituinte qualquer ocupando SpecCP. Para a autora, se o constituinte topicalizado para SpecCP da oração matriz é um elemento diferente do sujeito, como seria o caso dos exemplos (23) e (24), obrigatoriamente o sujeito da oração matriz será licenciado em posição pós-verbal, a saber, em SpecAgrSP, de acordo com a terminologia por ela adotada. Ou seja, na análise de Ribeiro, o padrão de inversão verbo-sujeito observado nesses exemplos seria resultante justamente da natureza V2 da gramática do português antigo.

Torres Morais (1993) apresenta evidências semelhantes às de Ribeiro (1995) de que o português, em fases passadas, caracterizava-se como um sistema V2. Por exemplo, em textos dos séculos XVI e XVII, período este comumente designado de português clássico, observa-se também que diferentes tipos de constituintes podem preceder imediatamente o verbo finito, como se vê em (25).

(25) a. No ano de 1550 mandou o Padre Manoel da Nóbrega os filhos dos índios ao campo.

b. Muito gostou o Fidalgo de o ouvir.

c. E assim o amava Felícia com grande medo. (Torres Morais, 1993, pp. 280-281)

A partir de (25), Torres Morais (1993) sugere que a posição imediatamente pré-verbal não é exclusiva do sujeito. $\mathrm{Na}$ visão da autora, isso pode ser tomado como uma evidência de que, nesse período, o português ainda se comporta como um sistema V2, ou seja, como uma gramática que instancia movimento sistemático do verbo para a periferia da sentença, com o deslocamento de um XP qualquer para a posição pré-verbal.

Torres Morais (1993) considera também que a maior evidência de que as sentenças com um elemento náo sujeito precedendo o verbo são ilustrativos da ordem V2 está nos casos que manifestam o sujeito após o auxiliar nos complexos verbais (Aux-S-V), como ilustrado em (26).

(26) Cada dia vão os Padres visitar os enfermos. 
De fato, o exemplo em (26) é semelhante ao padrão de inversão V-S de línguas V2, em que o sujeito segue imediatamente o verbo auxiliar. Esse padrão é exemplificado em (27) com um dado do alemão.

(27) Diesen Film haben die Kinder gesehen. (Vikner, 1995, p. 43)

Mais recentemente, a hipótese de que o português, em estágios passados, era um sistema gramatical de natureza V2 tem recebido apoio empírico de uma série de estudos quantitativos que fazem uso de grandes corpora (Paixão de Sousa, 2004; Galves, Britto, Paixão de Sousa, 2005; Antonelli, 2007, 2011 entre outros). Por exemplo, Antonelli (2011), com base num corpus formado por textos de escritores nascidos entre os séculos XVI e XIX ${ }^{36}$, mostra uma diferença significativa entre os textos de autores nascidos nos séculos XVI e XVII e os textos de autores nascidos nos séculos XVIII e XIX. Olhando para sentenças matrizes com ordem linear V2 e que manifestam um sujeito realizado foneticamente, em posição pré ou pós-verbal, o autor observa que a proporção percentual durante os séculos XVI e XVII entre a ordem de palavras S-V (sentenças com sujeito pré-verbal) e a ordem de palavras XPV-S (fronteamento com posposição do sujeito) apresenta um paradigma diferente daquele que é atestado para o período de tempo que corresponde aos séculos XVIII e XIX. Essa diferença pode ser visualizada na Tabela $2^{37}$.

Tabela 2. Sentenças matrizes com ordem linear V2. Dados em \%

\begin{tabular}{|l|c|c|c|c|}
\hline \multirow{2}{*}{} & \multicolumn{2}{|c|}{ S-V } & \multicolumn{2}{c|}{ XP-V } \\
\cline { 2 - 5 } & ocorrências & porcentagem & ocorrências & porcentagem \\
\hline Séc XVI & 461 & 52,38 & 419 & 47,62 \\
\hline Séc XVII & 542 & 44,20 & 684 & 55,80 \\
\hline Séc XVIII & 2088 & 81,75 & 466 & 18,25 \\
\hline Séc XIX & 1140 & 84,82 & 204 & 15,18 \\
\hline
\end{tabular}

36 Em seu trabalho, Antonelli (2011) faz uso de textos presentes no Corpus Tycho Brahe, um corpus eletrônico do português que disponibiliza acesso gratuito a todo seu conteúdo na rede mundial de computadores (cf. http://www.tycho.iel.unicamp.br/-tycho)

37 Resultados semelhantes para o mesmo período de tempo são encontrados em Paixão de Sousa (2004), Galves, Britto e Paixão de Sousa (2005) e Antonelli (2007), com a diferença de que estes trabalhos olham apenas para oraçóes com clíticos. 
Antonelli (2011) destaca que, nos textos escritos por autores nascidos até o fim do século XVII, parece não haver uma preferência ou por sentenças com sujeito pré-verbal ou por sentenças com um elemento não-sujeito precedendo o verbo. De fato, a média de frequência gira em torno de $50 \%$ para as duas opçóes de ordem de palavras. Em contraste a esse padrão, o que se observa a partir do século XVIII é uma curva de aumento na frequência de estruturas S-V. Como se vê, sentenças com sujeito pré-verbal passam a ser a sequência linear nitidamente mais empregada, com um índice de $81,75 \%$ no século XVIII e $84,82 \%$ no século XIX, resultando, consequentemente, no decréscimo de estruturas de fronteamento com ordem V-S.

Procurando interpretar esses resultados, Antonelli (2011) argumenta que o português dos séculos XVI e XVII pode ser caracterizado como um sistema gramatical V2. Para o autor, essa hipótese explica o porquê de sentenças com sujeito pré-verbal serem utilizadas numa frequência muito próxima da que é registrada para sentenças com um elemento não-sujeito em posição pré-verbal. De fato, diversos trabalhos já mostraram que, em línguas V2 prototípicas como as do ramo germânico, sentenças com sujeito pré-verbal geralmente não apresentam uma frequência superior a 70\% dos casos de ordem linear V2 (por exemplo, Jörgensen, 1976; Gerritsen, 1984; Bouma, 2008). Nesse sentido, então, os números relativos ao padrão de frequência da ordem $S-V$ no português dos séculos XVI e XVII constituem uma evidência quantitativa bastante robusta da proximidade do português desse período com os sistemas gramaticais V2. Por sua vez, do século XVIII em diante, a gramática do português não se caracterizaria mais como um sistema V2, tomando como base para essa afirmação o fato de que, a partir desse período, a superficialização do sujeito antes do verbo se torna a escolha mais empregada, uma espécie de opção default. Essa observação é corroborada pelo fato de que, na variante atual do português, como já mostrado, o fronteamento de qualquer tipo de sintagma náo altera necessariamente a superficializaçáo do sujeito em posição pré-verbal, o que seria também uma evidência de que a ordem $\mathrm{S}-\mathrm{V}$ é de fato uma estrutura do tipo default.

\subsection{A diferença estrutural das duas fases do português}

Procurando caracterizar a fase V2 e a fase não-V2 do português, Antonelli (2011) assume que, na gramática instanciada até o fim do século XVII, isto é, na fase V2, há movimento generalizado do verbo para a periferia da sentença, mais especificamente para o núcleo Fin, pensando-se aqui na proposta cartográfica para o nível da projeçáo CP. O sujeito seria linearizado em posição pré-verbal 
unicamente se houvesse algum requerimento determinando o seu deslocamento para SpecFinP (em se tratando de uma língua V2, tal requerimento corresponde ao traço EPP discutido em 2.1.3).

Em situações nas quais a restrição V2 é satisfeita por um constituinte diferente do sujeito, este último seria alçado no máximo até SpecIP, entendida aqui como uma posição exclusiva para o sujeito. Note-se que, nesta configuração, o verbo está numa posição hierarquicamente mais alta da que é ocupada pelo sujeito. Uma vez que SpecFinP não é uma posição exclusiva para sujeitos, já que outros sintagmas também podem satisfazer o traço EPP de Fin, é de se esperar, portanto, que sentenças V-S representem um padrão de ordem de palavras bastante empregado.

Com relação à gramática que se desenvolve a partir do século XVIII, isto é, a partir de quando começa a fase não-V2 da língua, a proposta é a de que o movimento do verbo ocorra apenas até o domínio de I. O sujeito, por sua vez, seria alçado para SpecIP, que ainda seria uma posição exclusiva para sujeitos. Nesta configuração, o verbo permanece numa posição hierarquicamente mais baixa da que é ocupada pelo sujeito, o que nos leva a prever um aumento na preferência por sentenças $S-V$, como confirmam os dados.

\section{O CONTATO DE LÍNGUAS E PERDA DO EFEITO V2 NO PORTUGUÊS E NO ESPANHOL}

Os dados discutidos acima e o conhecimento de alguns aspectos históricos levam à indagação das possíveis relaçóes entre questôes sócio-históricas e linguísticas. A discussão da evolução gramatical do português mostra uma direcionalidade similar à que é observada na história do espanhol: tanto numa língua como na outra, o que se tem é a mudança de um sistema gramatical V2 para um sistema gramatical não-V2, como foi discutido anteriormente por Fontana (1993), Ribeiro (1995) e Torres Morais (1993) e retomado por Pinto (2011) e Antonelli (2011). No caso do português, também é legítimo perguntar se tal mudança se deve somente a fatores internos ou se fatores externos influenciaram a mudança linguística.

Poderia ser argumentado que, na história do português, à semelhança do que Pinto (2011) propóe para o espanhol, a perda do efeito V2 está associada a um aumento no uso de estruturas de fronteamento de objeto com retomada clítica. A princípio, essa hipótese parece razoável, já que, tal como no espanhol antigo, o português anterior ao século XVIII também permitia o fronteamento de objetos não-focalizados sem ou com retomada clítica, como mostram os exemplos abaixo.

(28) a. E [esta carta] enviareis lloguo ao ministro, 
b. E [isto] sabe-o Deus e sabe-o Roma. (Gibrail, 2010, p. 89/118)

O fato a ser destacado, porém, é que, mesmo na variedade atual da língua, existe a opcionalidade de se ter um complemento fronteado retomado ou náo por um pronome resumptivo independente de questóes de focalização, como exemplificado em (29).

(29) a. O bolo, o Pedro comeu.

b. O bolo, o Pedro comeu-o. (Costa, 2004, p. 12)

O espanhol atual, como discutido em Rivero (1980) e Olarrea (1997), também permite construçóes de deslocamento à esquerda (sem clítico) - chamadas left dislocation como em (30):

(30) Dinero, dicen que Maria cree que mucho, si que tiene. ${ }^{38}$ (Rivero, 1980, p. 365)

O que está em jogo, portanto, é o fronteamento de objetos sem retomada clítica e o efeito V2 como equivalentes das construçôes de deslocamento à esquerda clítico - chamadas clitic left dislocation, construçóes que eram variáveis na fase antiga do espanhol como já mencionado acima. No caso do português, como a língua ainda continua exibindo ordem $\mathrm{O}-\mathrm{V}$ sem retomada clítica, como mostra o contraste em (29), a hipótese de que a mudança na manifestação do efeito V2 se deve exclusivamente a fatores internos perde força.

Neste trabalho, gostaríamos de problematizar, de acordo com a discussão de Martins (2003), se a mudança linguística no português é desencadeada por fatores externos. Mais especificamente, nossa hipótese é que essa mudança linguística poderia ser o resultado de uma situação de contato com o espanhol durante a Idade Média até a separação definitiva das coroas em 1640 (cf. também Paixão de Sousa, 2004).

Primeiramente, como já apontado na literatura especializada, destacamos que o espanhol/castelhano ${ }^{39}$ era a língua dominante em toda a Península Ibérica (cf. Lapesa, 1981; Cano Aguilar, 1997). Desde o desenvolvimento e expansão das

38 Como se discute em vários trabalhos e é retomado por Pinto (2011), a possibilidade de objetos tematizados sem retomada clítica só é possível quando o objeto é indefinido, conforme o exemplo de Rivero (1980).

39 É muito polêmica a questão de se a língua se chama "castellano" ou "español” tanto dentro como fora da Espanha. Não nos deteremos neste debate aqui. Para uma boa discussão histórica da questão, ver Alonso (1942).

Pinto CF, Antonelli AL. O Efeito V2 na história do espanhol e português europeus 
línguas românicas na Península Ibérica no começo do processo de Reconquista até o fim dos 1600, o espanhol/castelhano se caracteriza como uma língua de grande prestígio não apenas no que veio a ser o território atual da Espanha, mas também no espaço geográfico do reino português, tendo em vista o grande destaque dos reinos castelhanos neste período. Em Portugal, a aristocracia cultivava um ambiente de diglossia "espanhol-português" como indicativo de cultura e status social. A literatura portuguesa, dentro deste contexto, se viu bastante influenciada pela literatura espanhola dos Siglos de Oro, época de maior auge literário espanhol. Por exemplo, Martins (2003: 201) diz que das 46 peças de teatro que Gil Vicente escreveu, 19 eram bilíngues, 12 foram escritas em espanhol e 15 em português ${ }^{40}$.

O espanhol era falado como segunda língua em Portugal, o que, segundo Martins (2003), caracterizava uma variedade portuguesa do espanhol que a autora chama de Castillian of Portugal (Castelhano de Portugal). Recorrendo a conceitos da crioulística, a autora diz que o espanhol falado em Portugal era uma espécie de português relexificado, dadas suas semelhanças sintáticas com a língua de substrato (o português), exibindo, entre outros aspectos, infinitivo flexionado.

Outro aspecto a ser considerado diz respeito à cronologia da perda do efeito V2 nas duas línguas. Como já mostramos, no espanhol essa propriedade foi perdida entre os séculos XV e XVI. Já no português, as evidências trazidas para o debate por diferentes trabalhos apontam que a perda do efeito V2 aconteceu na passagem do século XVII para o século XVIII. Ou seja, em termos temporais, nota-se um lapso de tempo de 100 anos entre a mudança lingüística no espanhol e a mudança linguística no português.

Tendo em conta os aspectos apontados acima, a hipótese que formulamos é que a mudança linguística nas duas línguas teria se dado na seguinte dinâmica em quatro etapas:

1) Num estágio primeiro, de formação e consolidação dos dialetos regionais (cf. Walter, 1997), ambas as línguas possuíam uma gramática V2 devido às influências germânicas;

2) Num segundo momento, com o destaque dos reinos castelhanos durante a Reconquista, a gramática V2 do espanhol ainda manifestava estabilidade (e mais, foi reforçada pela chegada dos francos na Península Ibérica) e o impacto da situação de contato entre o português e o espanhol contribuía para que aquele também continuasse manifestando a propriedade $\mathrm{V} 2$. Ou seja, além de não haver um fator interno per se que pudesse desestabilizar o input dos indivíduos que adquiriam o português,

40 Martins (2003) nota que a relação entre as duas línguas era assimétrica: apenas Portugal vivia numa situação de bilinguismo.

Pinto CF, Antonelli AL. O Efeito V2 na história do espanhol e português europeus 
não havia também um fator externo, nesse caso, a pressão de uma língua de prestígio muito similar, que pudesse desestabilizar o ambiente linguístico em Portugal;

3) Um terceiro estágio acontece quando as evidências para a fixação da gramática V2 no espanhol passam a ser mais escassas no século XV, levando a uma consequente mudança gramatical nesta língua no século XVI;

4) Por fim, continua não havendo fatores internos no português que o levassem a uma mudança gramatical ${ }^{41}$. Contudo, dada a influência do espanhol na vida diária dos portugueses e o modelo linguístico dos escritores dos Siglos de Oro, que já não eram falantes de uma gramática V2, o português passa pela mudança gramatical perdendo a propriedade V2 entre os séculos XVII e XVIII.

O contato entre o português e o espanhol na sociedade portuguesa até o século XVII propiciou não somente a aparição de uma variedade do espanhol chamada por Martins (2003) de "Castelhano de Portugal" pelo menos na aristocracia e documentos escritos. Pode-se pensar, ademais, que o contato de línguas também provocou a mudança do português, tendo em vista que os modelos linguísticos e literários espanhóis dos Siglos de Oro exerceram bastante influência em partes da sociedade portuguesa do mesmo período.

Como a mudança linguística, dentro do quadro gerativista, é explicada a partir da fixação paramétrica diferente das geraçóes anteriores durante o processo de aquisição da linguagem, embora não houvesse nenhuma motivação interna inicial para a perda do efeito V2 no português, conforme aconteceu no espanhol, quando o espanhol perde o efeito V2 e continua influenciando o português como língua de superstrato, alguns falantes portugueses passam a usar construçóes não V2 decorrentes do contato, fazendo com que as crianças nascidas nesse ambiente não tivessem mais disponíveis evidências de que $o$ português era uma língua V2. Em outras palavras, a motivação interna para a mudança linguística no espanhol nasce de forma independente; no caso do português, essa mudança é decorrente do contato das duas línguas, que pode ter acelerado o gatilho também já existente no português.

\section{CONSIDERAÇÓES FINAIS}

Neste trabalho, olhamos para a diacronia do espanhol e do português no que diz respeito ao fenômeno V2 apresentando algumas das propostas centrais discutidas,

41 Talvez, já houvesse fatores internos que desencadeassem a mudança como as construções com "duplo que", conforme aponta Ilza Ribeiro, em comunicação pessoal, a partir do trabalho de Ribeiro e Torres Morais (2009), e esse gatilho tenha sido acelerado pela perda do efeito V2 no espanhol.

Pinto CF, Antonelli AL. O Efeito V2 na história do espanhol e português europeus 
independentemente, em nossas teses, Pinto (2011) e Antonelli (2011), às quais o leitor deverá se remeter para uma discussão mais minuciosa, com riqueza de dados empíricos e argumentação. Procuramos mostrar que o espanhol antigo era uma língua V2 e perdeu essa propriedade a partir do século XVI. Com relação ao português, procuramos mostrar que tal propriedade foi perdida a partir do século XVIII.

É certo que o tema escolhido é um campo de debate bastante fértil e controverso. Há um grupo de pesquisadores que defendem que as línguas românicas antigas são línguas V2 e há outro grupo de pesquisadores que defendem o contrário. Efetivamente, como discutido por Kayser (1999), há uma série de diferenças entre as línguas românicas antigas e as germânicas atuais com relação à ordem de constituintes e consequentemente com relação ao efeito V2, entre elas, menos restriçôes à ordem V1 e V>2 que o alemão atual. Kayser (1999) também pontua que há dados ambíguos entre uma gramática V2 e uma gramática não V2. A esse respeito, Pinto (2011) propõe, assumindo as discussóes de Roberts e Roussou (2003) que, uma vez fixada a opção mais marcada do parâmetro, a criança estende essa opção a todas as construçóes. Em termos concretos, a ordem S-V é ambígua para o linguista e não para a criança.

Em segundo lugar, a comparação das românicas antigas não pode ser feita com relação às germânicas atuais, já que diversos estudos mostram que as germânicas atuais exibem um efeito V2 diferente do que se encontrava nas germânicas antigas. Neste sentido, como já discutido por Fontana (1993), assumimos que efeito V2 não é uma restrição linear, mas, pelo contrário, é uma restrição estrutural que implica em movimento do verbo para CP, explicando-se assim, o porquê de tais diferenças: as línguas V2 não são um grupo de línguas uniforme nem homogêneo.

Tais questóes também estão relacionadas com o modelo teórico que se assume para explicar os fenômenos das línguas românicas antigas. Se uma visão cartográfica for assumida, há possibilidades de explicaçóes, a nosso ver, mais elegantes. Por exemplo, podemos explicar como o movimento do verbo para CP é perdido no espanhol e no português a partir de dados meramente empíricos (a diminuição de construçôes sem retomada clítica ${ }^{42}$ e a emergência de construções com "duplo que" ${ }^{\text {”33 }}$ ), que é o que a criança de fato tem para aprender sua língua ${ }^{44}$.

42 Esta hipótese é levantada por Pinto (2011). Contudo, outros aspectos também precisariam ser quantificados: a diminuição nas construçóes de object shift e na ordem Aux-S-V.

43 Essa hipótese de Ilza Ribeiro parece ser a correta. Mesmo que a ordem O-V sem retomada clítica tenha diminuído, havia outras características (a ordem Aux-S-V, principalmente) que poderia garantir um input robusto para as crianças. Pode-se pensar que, com a emergência das construçóes com "duplo que", todas as outras evidências de uma gramática V2 ficam opacas.

44 Não se pode esquecer que um dos pilares centrais da teoria gerativa é a adequação explicativa, 
Em outros modelos, como os de Rivero (1992) e Martins (2003), foi proposto que havia a possibilidade de adjunção à projeção intermediaria (X') no espanhol antigo, permitindo a ordem S-O-V, por exemplo. Esse modelo traz várias perguntas teóricas e empíricas. Em termos teóricos, como discutido pela própria Rivero (1992), umas línguas permitiriam adjunção à projeção intermediária e outras não. Pensando nas discussōes do Programa Minimalista, acreditamos que esta possibilidade é bastante incoerente com o formato de faculdade da linguagem proposto. Em termos empíricos, qual teria sido o gatilho para a perda do scrambling, ou adjunção a X', ao longo da história do português e do espanhol? E mais: uma vez que a proposta de explicação da mudança linguística dentro do quadro da gramática gerativa está relacionada com o processo de aquisição da linguagem (Lightfoot, 1991, 1998, 2006; Roberts e Roussou, 2003), quais seriam as evidências (ou falta delas) que a criança teria para mudar o tipo de adjunção durante o processo de aquisição?

Por fim, com relação ao tópico da influência do espanhol sobre o português, muitas questôes se levantam e devem ser motivo de futuras investigaçóes. Entre essas questôes: qual foi a real expansão do espanhol na sociedade portuguesa? Foi uma expansão geral a toda sociedade ou estava restrita a um grupo determinado? Como o espanhol influenciou efetivamente a mudança linguística em Portugal? Nosso trabalho pretendeu mostrar um ponto de discussão que pode trazer novas questóes e novos elementos para a história das duas línguas, deixando aberto um campo que pode render muitos frutos positivos para o seu estudo.

\section{REFERÊNCIAS}

Adams M. Old french, null subjects and verb second phenomena [Tese de Doutorado]. Los Angeles: University of California; 1987.

Alonso A. Castellano, español, idioma nacional: historia espiritual de tres nombres. 2 ed. Buenos Aires: Losada; 1942.

Antonelli A. Sintaxe de posição do verbo e mudança gramatical na história do português europeu [Tese de Doutorado]. Campinas: Universidade Estadual de Campinas; 2011.

ou seja, como uma criança sai do estado inicial da faculdade da linguagem e chega a uma língua particular. Em adição, quando é assumido que a aquisição da linguagem é o ponto central da mudança linguística, qualquer teoria que se faça sobre as línguas tem que pensar em como essa mudança foi implementada a partir do processo de aquisição da linguagem. 
Antonelli A. O Clítico SE e a variação ênclise/próclise do português médio ao português europeu moderno [Tese de Doutorado]. Campinas: Universidade Estadual de Campinas; 2007.

Biberauer T. Verb second in afrikaans: is this a unitary phenomenon?. Stellenbosch Papers in Linguistics. 2002;34:19-69.

Bobaljik J, Jonas D. Subject positions and the roles of IP. Linguistic Inquiry. 1996;27:195-236.

Bouma G. Starting a sentence in dutch [Tese de Doutorado]. Groningen: Universidade de Groningen; 2008.

Cano Aguilar R. El español a través de los tiempos. Madrid: Arco/Libros; 1997.

Chirita D. Did latin influence german word order? Aspects of german-latin bilingualism in the Late Middle Ages. In: Braunmüller K, Ferraresi G, organizadores. Aspects of multilingualism in european language history. Amsterdam/Philadelphia: John Benjamins; 2003. p. 173-200.

Chomsky N. El programa minimalista. Trad.: Juan Romero Morales. Madrid: Alianza; 1995.

Chomsky N. Knowledge of language: Its nature, origin and use. New York: Praeger; 1986a.

Chomsky N. Barriers. Cambridge, Mass.: The MIT Press; 1986b.

Chomsky N. Lectures on government and binding. Dordrecht: Foris; 1981.

Cinque G. Bare quantifiers, quantified NPs, and the notion of operator at S-structure. In: Cinque G. Italian syntax and Universal Grammar. Nova Iorque: Cambridge University Press; 1995. p. 104-120.

Cinque G, Rizzi L. The cartography of syntactic structures. CISCL Working Papers. 2008;2:45-58.

Costa J. Subject positions and interfaces: the case of european portuguese. Berlim/N. Iorque: Mouton de Gruyter; 2004. 
Costa J. Spec, IP ou deslocado? Prós e contras das duas análises dos sujeitos pré-verbais. D.E.L.T.A. 2001;17(2):283-303.

Costa J. Word order variation [Tese de Doutorado]. Leiden: Universidade de Leiden; 1998.

Cruschina S, Sitaridou I. From modern to old romance: the interaction between information structure and word order. In: The XI Diachronic Generative Syntax Conference. Campinas: Unicamp; 2009.

Demonte V, Fernández-Soriano O. Force and finiteness in the Spanish complementizer system. Probus. 2009;21:23-49.

Den Besten H. On the interaction of root transformations and lexical deletive rules. Studies in West Germanic Syntax. 1989;20:14-100.

DIESING M. Verb movement and the subject position in Yiddish. Natural Language and Linguistic Theory. 1990;8:41-79.

Fernández-Ordóńez I. Orden de palabras, tópicos y focos en la prosa alfonsí [Manuscrito]. Madrid: Universidad Autónoma de Madrid; 2009.

Fontana JM. Phrase structure and the syntax of clitics in the history of Spanish [Tese de Doutorado]. Pensilvânia: University of Pennsylvania; 1993.

Galves C. Do português clássico ao português europeu moderno: uma análise minimalista. Estudos Linguísticos e Literários. 1997;19:105-128.

Galves C, Britto H; Paixão de Sousa MC. The change in clitic placement from classical portuguese to modern european portuguese: results from the Tycho Brahe Corpus. Journal of Portuguese Linguistics. 2005;1:36-67.

Gerritsen M. Divergent word order developments in germanic languages: a description and a tentative explanation. In: Fisiak J, organizador. Historical syntax. Amsterdam: Mouton; 1984. p. 107-135.

Gibrail A. Contextos de formação de estruturas de tópico e foco no português clássico [Tese de Doutorado]. Campinas: Universidade Estadual de Campinas; 2010. 
Guerras MS. Os povos bárbaros. 3 ed. São Paulo: Ática; 1995.

Haider H, Prinzhorn M. Introduction. In: Haider H, Prinzhorn M, organizadores. Verb second phenomena in germanic languages. Dordrecht: Foris; 1986. p. 1-6.

Hernanz ML, Brucart JM. La sintaxis. Princípios teóricos. La oración simple. Barcelona: Crítica; 1987.

Hinterhölzl R, PetrovaS. From V1 toV2 in West Germanic. Lingua. 2010;120(2):315-328.

Jörgensen N. Meningsbyggnaden i Talad Svenska. Lund: Studentlitteratur; 1976.

Julien M. Embedded clauses with main clause word order in Mainland Scandinavian [manuscrito]; 2010.

Kayne R. The antisymmetry of syntax. Cambridge: MIT Press; 1994.

Kayser G. Sobre a alegada perda do sujeito nulo no português brasileiro. In: Lobo T et alii, organizadores. Para a história do português brasileiro, v. 6, tomo 2. Salvador: EDUFBA; 2006. p. 11-42.

Kayser G. A ordem das palavras e a posição do verbo finito no português antigo. In: Actas do Congresso Internacional Organizado por Motivo dos Vinte Anos do Português no Ensino Superior. Budapeste: Departamento de Língua e Literatura Portuguesas da Faculdade de Letras da Universidade Etövös Loránd; 1999. p. 248-259.

Kremer D. Hispania Germânica. En torno a las relaciones linguísticas germano-hispanicas. In: Hempel W, Briesemeister D, organizadores. Actas del Colóquio hispano-alemán Ramón Menéndez Pidal. Tübingen: Max Niemeyer Verlag; 1982. p. 138-149.

Kroch A. Syntactic change. In: Baltin M; Collins C, organizadores. The handbook of contemporary syntactic theory. Oxford: Blackwell; 2001. p. 699-730.

Lapesa R. Historia de la lengua espańola. 9 ed. Madrid: Gredos; 1981.

Lightfoot D. How new languages emerge. Cambridge: Cambridge University Press; 2006. 
Lightfoot D. Cue-based acquisition and change in grammars. In: Lightfoot D. The development of language, acquisition, change and evolution. Oxford: Blackwell; 1998. p. 144-177.

Lightfoot D. How to set parameters: arguments from language change. Cambridge/ Massachucetts: The MIT Press; 1991.

Lightfoot D. Principles of diachronic syntax. Cambridge: Cambridge University Press; 1979 .

Martins AM. From unity to diversity in romance syntax: A diachronic perspective of clitic placement in Portuguese and Spanish. In: Braunmüller K, Ferraresi G, organizadores. Aspects of multilingualism in european language history. Amsterdam/Philadelphia: John Benjamins; 2003. p. 201-233.

Mensching G. Old romance word order: a comparative minimalist analysis. In: The XI Diachronic Generative Syntax Conference. Campinas: Unicamp; 2009.

Olarrea A. Pre- and postverbal subject positions in spanish: a minimalist account [Tese de Doutorado]. Washington: University of Washington; 1997.

Paixão de Sousa MC. Língua barroca: sintaxe e história no português nos anos 1600 [Tese de Doutorado]. Campinas: Universidade Estadual de Campinas; 2004.

Pinto CF. Ordem de palavras, movimento do verbo e efeito V2 na história do espanhol [Tese de Doutorado]. Campinas: Universidade Estadual de Campinas; 2011.

Pinto CF. Orden OV, duplicación clítica y estructura informativa en la historia del espańol. In: III Simpósio Internacional de Lengua Española. São Paulo: Instituto Cervantes; 2010.

Ribeiro I. Completivas com duplo-que no português arcaico. In: Lobo T et al, organizadores. ROSAE: linguística histórica, história das línguas e outras histórias. 1 ed. Salvador: EDUFBA; 2012. p. 75-92.

Ribeiro I. A sintaxe da ordem no português arcaico: o efeito V2 [Tese de Doutorado]. Campinas: Universidade Estadual de Campinas; 1995. 
Ribeiro I.; Torres Morais MA.. Doubling-que embedded constructions in old portuguese: a diachronic perspective. In: The XI Diachronic Generative Syntax Conference. Campinas: Unicamp; 2009.

Rinke E. Verb placement in old portuguese. In: Dufter A, Jacobs D, organizadores. Focus and background in romance languages. Amsterdam: John Benjamins; 2009. p. 309-332.

Rivero ML. Clitic and NP Climbing in Old Spanish. In: Campos H, Martinez-Gil, Organizadores. Current studies in spanish linguistics. Washington: Georgetown University Press; 1992. p. 241-282.

Rivero ML. On left dislocation and topicalization in spanish. Linguistic Inquiry. 1980;11(2):363-393.

Rizzi L. The fine structure of the left periphery. In: Haegeman L, organizador. Elements of grammar. Kluwer: Dordrecht; 1997. p. 281-337.

Roberts I. Diachornic syntax. Nova Iorque: Oxford University Press; 2007.

Roberts I. The C-Systen in brythonic celtic languages, V2 and the EPP. In: Rizzi L, organizador. The Structure of CP and IP. The cartography of syntactic structures. v. 2. Oxford: Oxford University Press; 2004. p. 297-328.

Roberts I, Roussou A. Syntactic change: a minimalist approach to grammaticalization. Cambridge: Cambridge University Press; 2003.

Santorini B. Two types of verb second in the history of Yiddish. In: Battye A; Roberts I, organizadores. Clause structure and language change. Nova Iorque, Oxford: Oxford University Press; 1995. p. 53-79.

Santorini B. The generalization of the verb-second constraint in the history of Yiddish [Tese de Doutorado]. Pensilvânia: University of Pennsylvania; 1989.

Suñer M. V-movement and the licensing of argumental wh-phrases in Spanish. Natural language and linguistic theory. 1994;12:335-372. 
Taraldsen KT. On verb second and the functional content of syntactic categories. In: Haider H, Prinzhorn M, organizadores. Verb second phenomena in germanic languages. Dordrecht: Foris; 1986. p. 7-25.

Thráinsson H. V1, V2 e V3 in Icelandic. In: Haider H, Prinzhorn M, organizadores. Verb second phenomena in germanic languages. Dordrecht: Foris; 1986. p. 169-194.

Torres Morais MA. Do português clássico ao português europeu moderno: um estudo diacrônico da cliticização e do movimento do verbo [Tese de Doutorado]. Campinas: Universidade Estadual de Campinas; 1995.

Torres Morais MA. Aspectos diacrônicos do movimento do verbo, estrutura da frase e caso nominativo no português do Brasil. In: ROBERTS I, KATO M, organizadores. Português brasileiro: uma viagem diacrônica. Campinas: Editora da Unicamp; 1993. p. 263-306.

Tuten D. Koineization in Medieval Spanish. Berlin/Nova Iorque, Mouton de Gruyter; 2003.

Vikner S. Verb movement and expletive subjects in the Germanic languages. Oxford: Oxford University Press; 1995.

Walter H. A Aventura das línguas no ocidente: a sua origem, a sua história, a sua geografia. Trad.: de Sérgio Cunha dos Santos. São Paulo: Mandarim; 1997.

Zubizarreta ML. Prosody, focus, and word order. Cambridge, Mass.: The MIT Press; 1998. 